\title{
Decolorization of Disperse Dyes Using Immobilized Laccase Enzyme on Nano Zinc Ferrite from Single and Binary Systems
}

\author{
Hossein Farrehi*, Khashayar Mohajer Shojaei, Ali Farrahi, Ahmad Farrahi \\ Farrokh Sepehrkashan Textile Company, Farrahi-Mr carpet GMBH, Tehran, Iran \\ Email: ^Khashayar045@yahoo.com
}

How to cite this paper: Farrehi, H., Shojaei, K.M., Farrahi, A. and Farrahi, A. (2017) Decolorization of Disperse Dyes Using Immobilized Laccase Enzyme on Nano Zinc Ferrite from Single and Binary Systems. Materials Sciences and Applications, 8, 566576.

https://doi.org/10.4236/msa.2017.87039

Received: March 25, 2017

Accepted: July 16, 2017

Published: July 19, 2017

Copyright $(9) 2017$ by authors and Scientific Research Publishing Inc. This work is licensed under the Creative Commons Attribution International License (CC BY 4.0).

http://creativecommons.org/licenses/by/4.0/

\begin{abstract}
In this paper, immobilized laccase enzyme on nano zinc ferrite was used in order to decolorize disperse dyes from single and binary systems. In this case, disperse dyes such as Disperse red 60 (DR60), Disperse blue 56 (DB56) and Disperse yellow 54 (DY54) were selected as model dyes. Several parameters such as enzyme concentration, $\mathrm{pH}$ and dye concentration and their effect on decolorization of dyes from single and binary systems were studied. According to the experimental results, the optimized immobilized laccase enzyme concentration, reaction time and $\mathrm{pH}$ for decolorization of DR60, DB56 and DY54 from single and binary systems were $500 \mathrm{mg} / \mathrm{L}$ (for DR60 and DY54) and $400 \mathrm{mg} / \mathrm{L}$ (for DB56), $20 \mathrm{~min}$ and 3, respectively. Moreover, Dye decolorization kinetics followed Michaelis-Menten Model. Finally, the results showed that enzymatic process using immobilized laccase enzyme on nano zinc ferrite was effective method to decolorize disperse dyes from single and binary systems.
\end{abstract}

\section{Keywords}

Enzymatic Decolorization, Immoblizedlaccase Enzyme, Single and

Binary Systems, Michaelis-Menten Model, Disperse Dyes, Nano Zinc Ferrite

\section{Introduction}

Dye removal of industrial effluent has been a major concern in wastewater treatment, especially for textile and dyestuff plants.

Enzymatic processes are frequently applied to decolorize textile and dyestuff wastewater due to the cost effectiveness [1] [2] [3].

Alternatively, enzymatic oxidation of dye using Laccase has received great attention in recent years due to the high efficient dye decolorization [4]. 
Laccases from white rot fungi are potential industrial enzymes in various applications such as pulp delignification, wood fiber modification, chemical or medicinal synthesis and waste water treatment [5].

Different factors such as highly polluted waste water and mediator-by products have significant effect on decreasing of stability and catalytic ability of free enzyme. Therefore, finding suitable solution to overcome this problem is important subject [6].

Laccase enzymes from white rot fungi with high enzymatic activity have found many applications in various industries, such as pulp delignification, wood fiber modification, chemical or medicinal syntheses, and wastewater treatment [7].

The stability and the activity of free enzyme are reduced in the presence of highly polluted wastewater. Thus, finding suitable solutions to overcome this difficulty is an important subject [8]. The immobilization of enzymes is one approach to this; it increases the stability and prolongs the shelf-life of the enzyme in solution [9].

Different methods can be used for the immobilization of enzymes on different substrates:

A) Activation of the enzyme by suitable chemical reactions before immobilization on the carrier.

B) Modifying the carrier before the immobilization process.

C) Using cross-linking agent such as glutaraldehyde to mediate between the carrier and the enzyme functional groups [10].

Immobilized substrate based on the last method retains high enzymatic activity and is effective in dye degradation over a wide range of $\mathrm{pH}$ and temperature [8] [9]. Different mechanisms (e.g., adsorption, entrapment, encapsulation, and covalent coupling) can be used for immobilization of free laccase enzyme on various carriers [11]. The performance of immobilized enzyme largely depends on the structure of the support. The support can be inorganic (e.g., nanoTiO2) or a modified polymer (e.g., polypropylene) [12].

In this paper, enzymatic decolorization of dye using from single and binary systems was studied.

Disperse red 60 (DR60), Disperse blue 56 (DB56) and Disperse yellow 54 (DY54) were used as a model dyes. The effect of several parameters such as enzyme concentration, $\mathrm{pH}$ and dye concentration on decolorization of dyes from single and tertiary systems was evaluated.

\section{Experimental}

\subsection{Materials}

Disperse red 60 (DR60), Disperse blue 56 (DB56) and Disperse yellow 54 (DY54) were obtained from Youhao company. The chemical structure of dyes was shown in Figure 1. Free laccase enzyme (Denilite II S) was provided by Novo Nordisk Company. $\gamma$-Amino propyl triethoxysilane and gluteraldehyde were obtained from Sigma-Aldrich. All other chemicals were of analytical grade and purchased from Merck Company (Germany). 


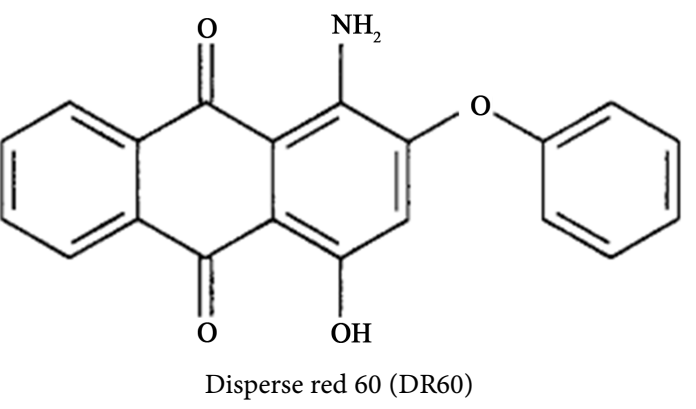<smiles>Nc1ccc(O)c2c1C(=O)c1c(O)cc(Br)c(N)c1C2=O</smiles>

Disperse blue 56 (DB56)<smiles>O=C1c2ccccc2C(=O)C1c1nc2ccccc2cc1O</smiles>

Disperse yellow 54 (DY54)

Figure 1. The chemical structure of disperse dyes.

\subsection{Laccase Immobilization}

Zinc ferrite nanoparticle was synthesized in previously published paper [13]. Zinc ferrite nanoparticle was silanized by immersing in a $4 \%(\mathrm{v} / \mathrm{v}) \gamma$-amino propyl triethoxysilanein acetone solution at $45^{\circ} \mathrm{C}$ for $24 \mathrm{~h}$. The silanized zinc ferrite nanoparticle was washed thoroughly with distilled water and then immersed in $2 \%(\mathrm{v} / \mathrm{v})$ of aqueous glutaraldehyde solution for $2 \mathrm{~h}$ at room temperature. After washing of obtained nanoparticle with distilled water, they were dried at $60^{\circ} \mathrm{C}$ for $1 \mathrm{~h}$. Thereafter, $5 \mathrm{~g}$ obtained nanoparticles were immersed in given amount of free laccase for $48 \mathrm{~h}$ at room temperature.

\subsection{Characterization Methods}

FTIR and SEM were used for analyzing compositions, dimensions and morphology of samples. FTIR spectroscopy was used for determining functional groups of materials.

PHILIPS scanning electronic microscope was used for studying morphology of materials

\subsection{Dye Decolorization}

Experiments were carried out in a batch mode reactor with total capacity of 250 $\mathrm{mL}$. Decolorization of dyes was performed using a $100 \mathrm{~mL}$ solution containing 
specified concentration of dye using immobilized Laccase enzyme on nano zinc ferrite.

The solution $\mathrm{pH}$ was adjusted using $\mathrm{HCl}$ or $\mathrm{NaOH}$. Samples were withdrawn from sample point at certain time intervals and analyzed for dye degradation.

Dye degradation was checked and controlled by measuring the absorbance at maximum wavelength $\left(\lambda_{\max }\right)$ of dyes at different time intervals using UV-vis spectrophotometer (Perkin-Elmer Lambda 25 spectrophotometer).

The effect of free laccase enzyme concentration on dye degradation was investigated by contacting $100 \mathrm{~mL}$ of dye solution $(20 \mathrm{ppm})$ at $45^{\circ} \mathrm{C}$ and $\mathrm{pH} 3$. Different enzyme concentrations $(200,300,400$ and 500 ppm) were applied.

The effect of $\mathrm{pH}(3-9)$ on dye degradation was investigated by contacting 100 $\mathrm{mL}$ of dye solution $(20 \mathrm{ppm})$ and enzyme concentration $(500 \mathrm{ppm})$ at $45^{\circ} \mathrm{C}$.

The effect of initial dye concentration (10 - $50 \mathrm{ppm}$ ) on dye degradation was investigated by contacting $100 \mathrm{~mL}$ of dye solution and enzyme concentration (500 ppm) at $45^{\circ} \mathrm{C}$ and $\mathrm{pH} 3$.

In single system, concentration of dye and its variation during enzymatic processes are measured due to the Beer-Lambert law.

$$
A=\varepsilon L C
$$

where $\varepsilon, L$ and $C$ are extinction coefficient $(\mathrm{L} / \mathrm{mg} \mathrm{cm})$, path length $(\mathrm{cm})$ and dye concentration (ppm), respectively.

Dye concentrations were calculated as follows. For a binary system of components $\mathrm{A}$ and $\mathrm{B}$ measured at $\lambda_{1}$ and $\lambda_{2}$, respectively, to give optical densities of $d_{1}$ and $d_{2}[3]$ :

$$
\begin{aligned}
& C_{A}=\left(k_{B 2} d_{1}-k_{B 1} d_{2}\right) /\left(k_{A 1} k_{B 2}-k_{A 2} k_{B 1}\right) \\
& C_{B}=\left(k_{A 1} d_{2}-k_{A 2} d_{1}\right) /\left(k_{A 1} k_{B 2}-k_{A 2} k_{B 1}\right)
\end{aligned}
$$

where $k_{\mathrm{A} 1}, k_{\mathrm{B} 1}, k_{\mathrm{A} 2}$, and $k_{\mathrm{B} 2}$ are the calibration constants for components $\mathrm{A}$ and $\mathrm{B}$ at the two wavelengths $\lambda_{1}$ and $\lambda_{2}$, respectively.

\section{Results and Discussion}

\subsection{Enzyme Concentration}

Decolorization of dyes from single and binary systems at different concentrations of enzyme is shown in Figure 2. The results show that with increasing immobilized laccase enzyme concentration, the dye removal percentage increases gradually because of existence of moreenzyme molecules at the expense of fixed amount of dye molecules [5] [14].

Furthermore, the optimized amount of immobilized enzyme laccase enzyme, reaction time and $\mathrm{pH}$ for decolorization of DR60, DB56 and DY54 from single and binary systems were $500 \mathrm{mg} / \mathrm{L}$ (for DR60 and DY54) and $400 \mathrm{mg} / \mathrm{L}$ (for DB56), 20 min respectively.

\section{2. $\mathrm{pH}$}

Decolorization of dyes from single and binary systems at different $\mathrm{pH}$ is shown in Figure 3. 


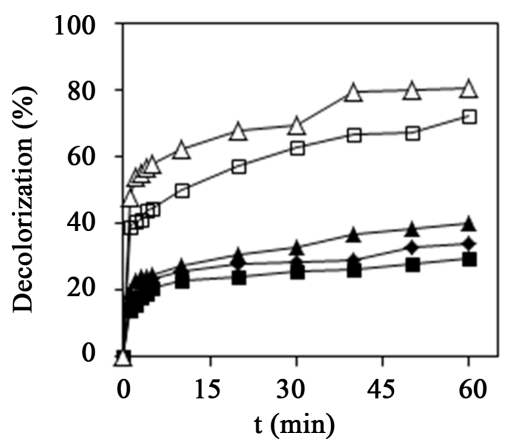

(a)

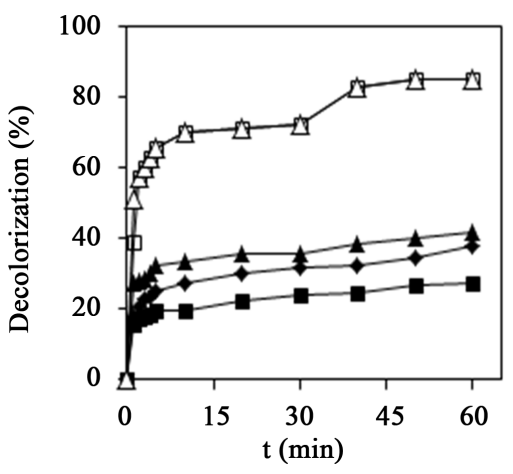

(c)

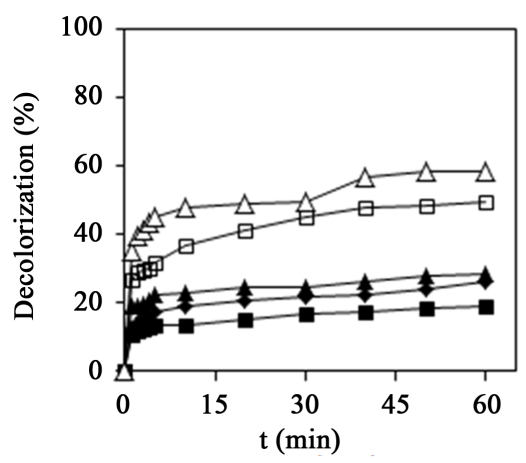

(e)

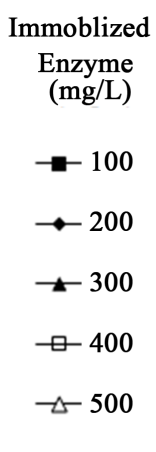

Immoblized

Enzyme

(mg/L)

$-100$

$\rightarrow-200$

$-300$

$\multimap-400$

$\triangle 500$

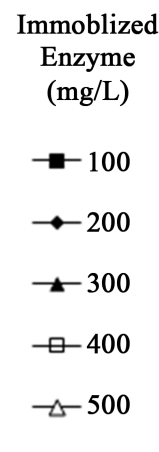

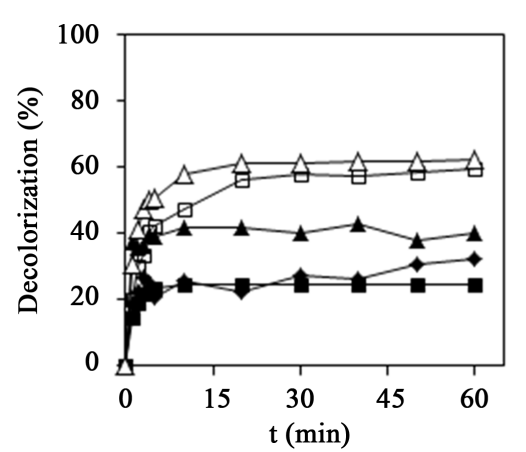

Immoblized

Enzyme

(mg/L)

$-100$

$\multimap 200$

$-300$

$\square-400$

$\triangle-500$

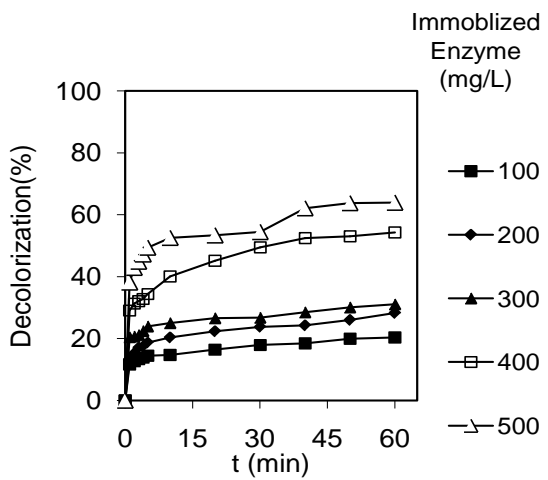

(d)

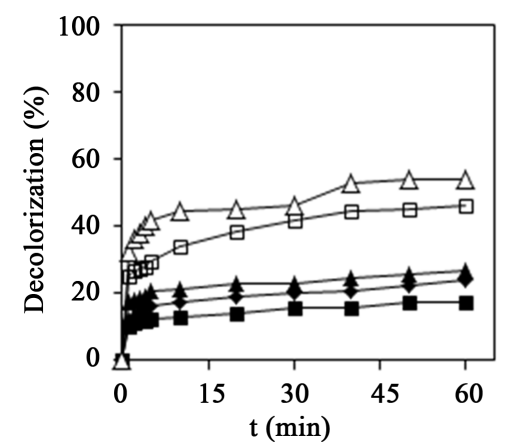

$$
\begin{gathered}
\begin{array}{c}
\text { Immoblized } \\
\text { Enzyme } \\
(\mathrm{mg} / \mathrm{L})
\end{array} \\
\rightarrow-100 \\
\rightarrow-200 \\
\leftarrow 300 \\
\square-400 \\
-\triangle 500
\end{gathered}
$$

(f)

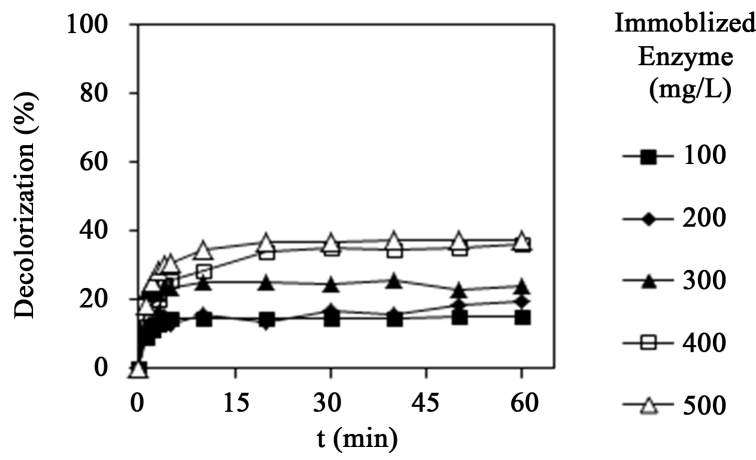

(g)

Figure 2. The effect of immobilized laccase enzyme concentration on enzymatic decolorization of dyes from single and binary systems. ((a)-(c): single system; (e): DR60-DB56, (f)-(g):DR60-DY54). (a) DR60; (b) DY54; (c) DB56; (d) DR60 in binary system (DR60-DB56); (e) DB56 in binary system (DR60-DB56); (f) DR 60 in binary system (DR60-DY54); (g) DY 54 in binary system (DR60-DY54). 


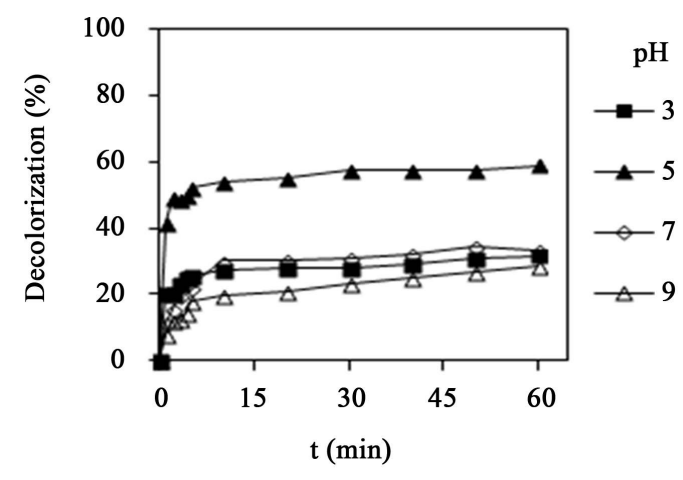

(a)

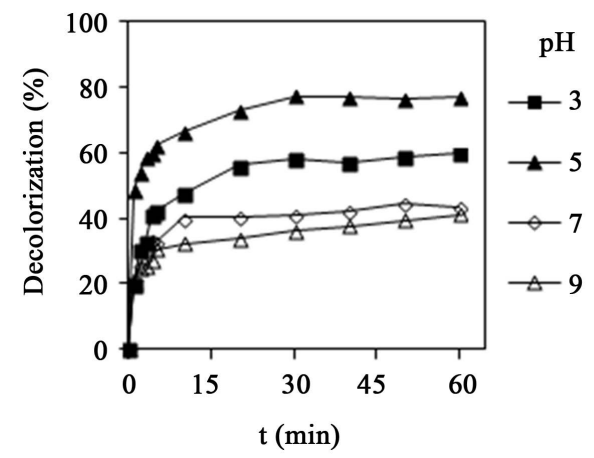

(c)

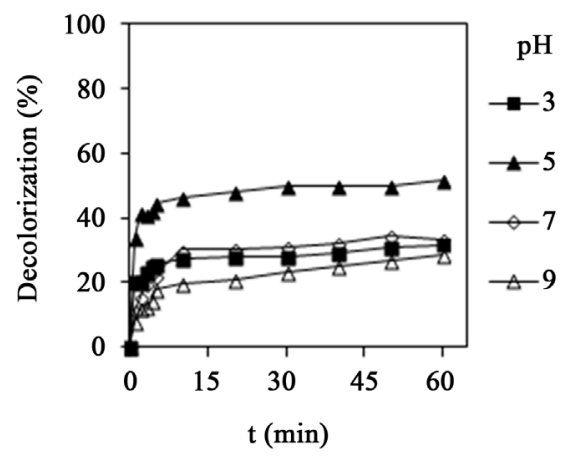

(e)

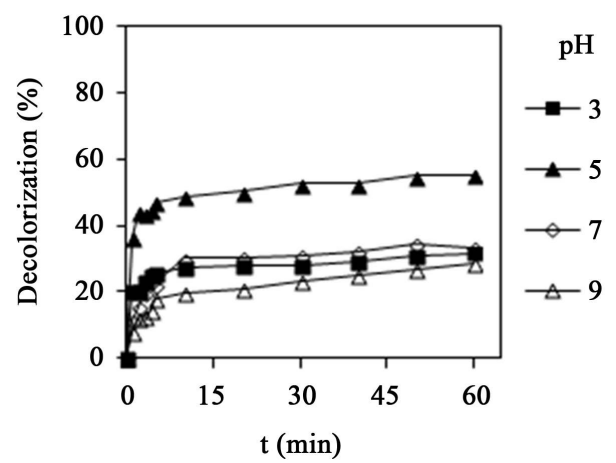

(b)

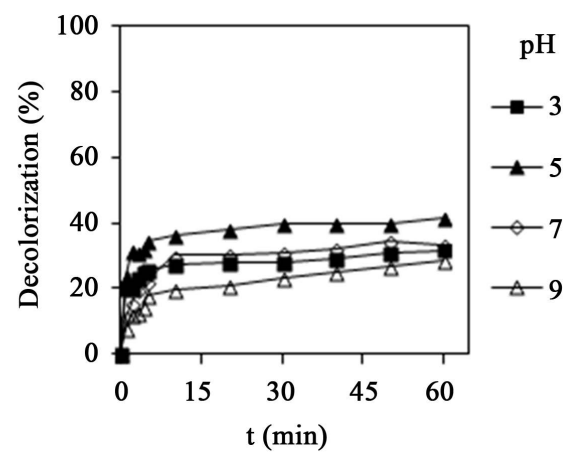

(d)

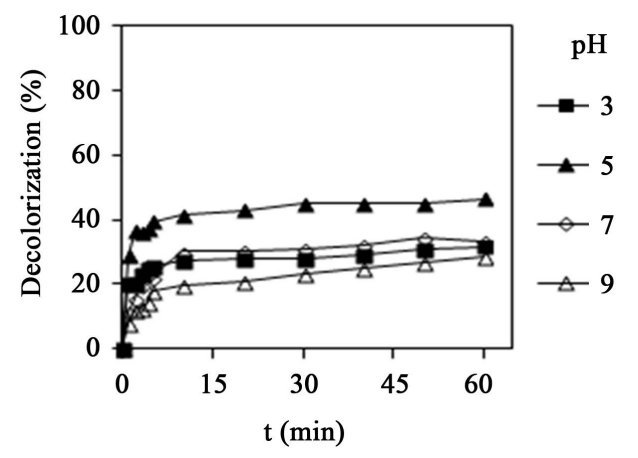

(f)

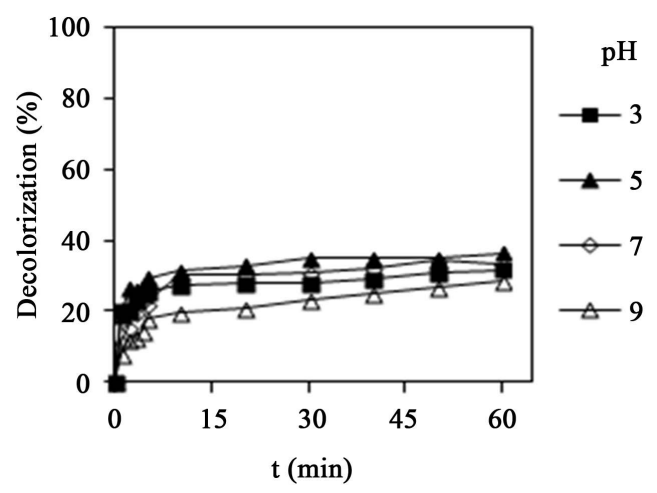

(g)

Figure 3. Effect of pH on enzymatic decolorization of dyes from single and binary systems. ((a)-(c): single system; (e): DR60DB56; (f) and (g): DR60-DY54). (a) DR60; (b) DY54; (c) DB56; (d) DR60 in binary system (DR60-DB56); (e) DB56 in binary system (DR60-DB56); (f) DR 60 in binary system (DR60-DY54); (g) DY 54 in binary system (DR60-DY54). 
The results showed that the $\mathrm{pH}$ significantly influenced theimmobilized laccase enzyme action during dye decolorization. Dye decolorization was found to improve with an increase in aqueous phase $\mathrm{pH}$ until a value of 5.0 and thereafter an increase in the aqueous phase $\mathrm{pH}$ from 3.0 to 9.0 caused the efficacy of enzymatic decolorization process to decrease.

The aqueous phase $\mathrm{pH}$ of 5.0 had significant effect on the rate of dye decolorization compared to other $\mathrm{pH}$ conditions. Thus, aqueous phase $\mathrm{pH}$ plays a significant role in enzymatic reactions and many free enzymes exhibit maximum activity at one particular $\mathrm{pH}$. In addition, the $\mathrm{pH}$-activity relationship of any given freeenzyme depends on the acid-base behavior of freeenzyme and substrate as well as many other factors that are usually difficult to analyze quantitatively [5] [15].

\subsection{Dye Concentrations}

Decolorization of dyes from single and binary systems at different dye concentrations is shown in Figure 4. Results showed that increasing of dye concentration leads to reduce dye decolorization because of existence of more dye molecules. This phenomena show that the aqueous phase dyes concentration influenced the immobilizedenzyme activity. When the amount of immobilized laccaseenzyme concentration was kept constant and the substrate (dye) concentration was gradually increased, the velocity of reaction increases until it reached the maximum. After obtaining the equilibrium state, any further addition of substrate (dye) did not alter the rate of reaction [16].

\subsection{Kinetic of Dye Decolorization Processes}

Kinetic of enzymatic decolorization of dyes has been studied according to the substrate (dye) absorption and enzymatic reaction rate. To investigate the mechanism, a Michaelis-Menten constant has been used to fit the experimental data. The kinetic constant, Michaelis-Menten $\left(\mathrm{K}_{\mathrm{m}}\right)$, Maximum decolorization rate $\left(\mathrm{V}_{\max }\right)$ and catalytic constant $\left(\mathrm{K}_{\mathrm{cat}}\right)$ of laccase were determined for dyes from single and binary systems by linear regression and Hanes-Woolf plots (Table 1) [16].

Table 1. Kinetic constants of enzymatic decolorization of dyes from single and binary systems using immobilized Laccase.

\begin{tabular}{cccc}
\hline Substrate & $\mathrm{K}_{\mathrm{m}}(\mu \mathrm{M})$ & $\mathrm{V}_{\max }(\mathrm{mg} / \mathrm{L} \mathrm{min})$ & Kcat \\
\hline $\begin{array}{c}\text { Disperse red 60 in single system } \\
\text { Disperse blue 56 in single system }\end{array}$ & 1.848 & 0.00136 & 0.00221 \\
Disperse yellow 54 in single system & 1.8121 & 0.00118 & 0.00198 \\
Disperse red 60 in DR60/DB56 & 3.052 & 0.00143 & 0.00128 \\
Disperse blue 56 in DR60/DB56 & 6.09 & 0.00326 & 0.00180 \\
Disperse red 60 in DR60/DY54 & 1.946 & 0.00117 & 0.00176 \\
Disperse yellow 54 in DR60/DY54 & 6.731 & 0.00357 & 0.00187 \\
\hline
\end{tabular}




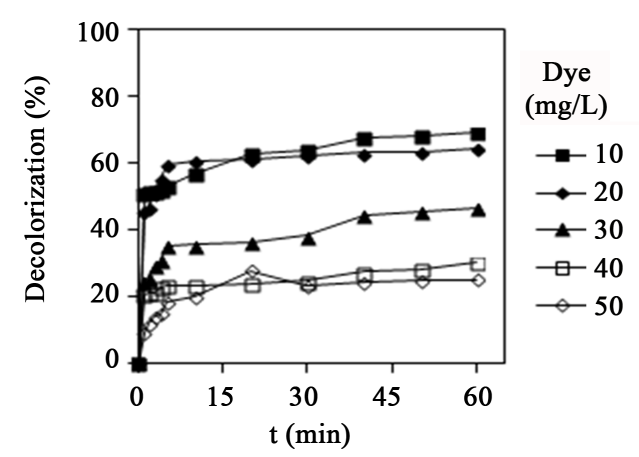

(a)

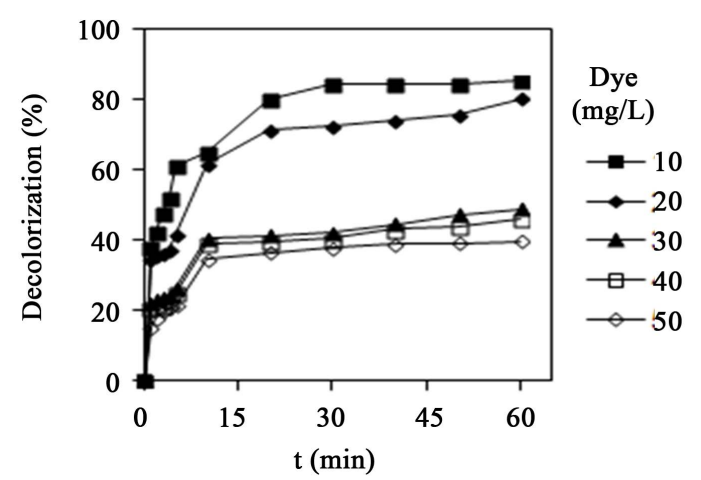

(c)

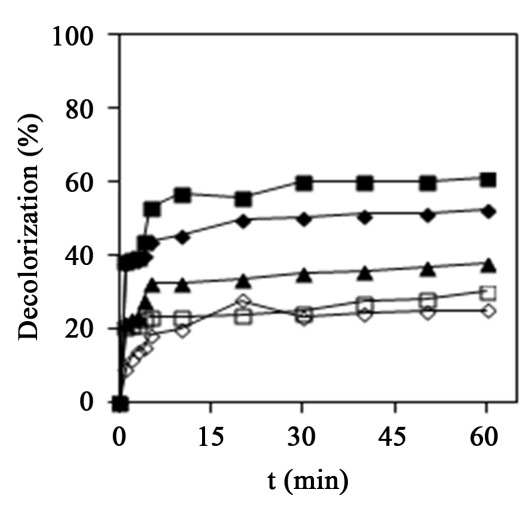

(e)

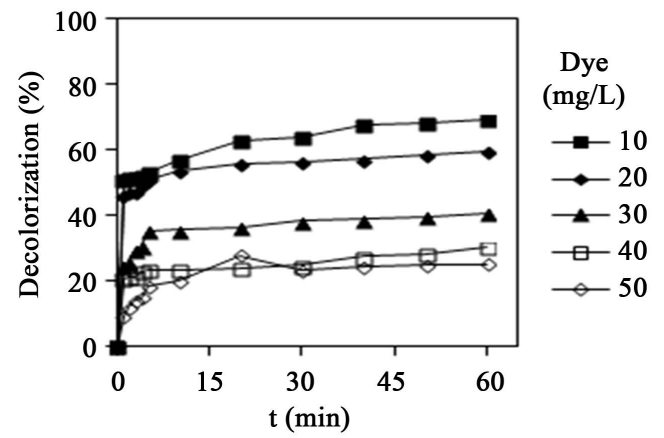

(b)

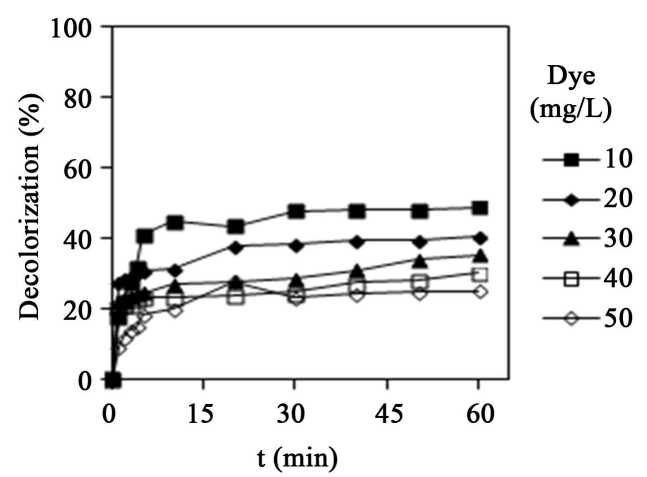

(d)

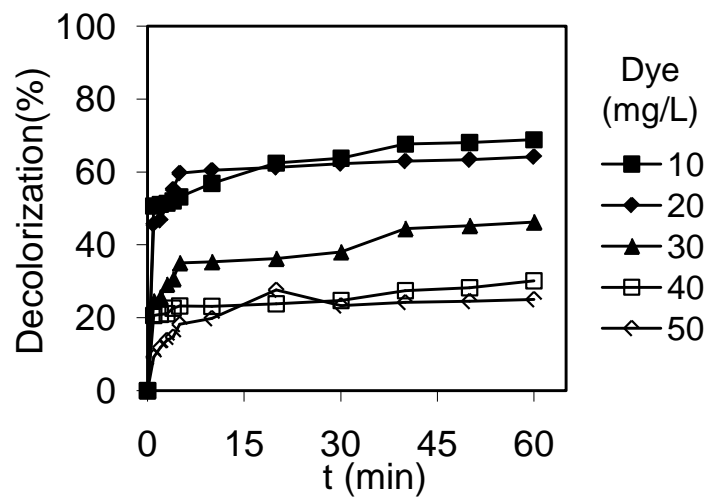

(f)

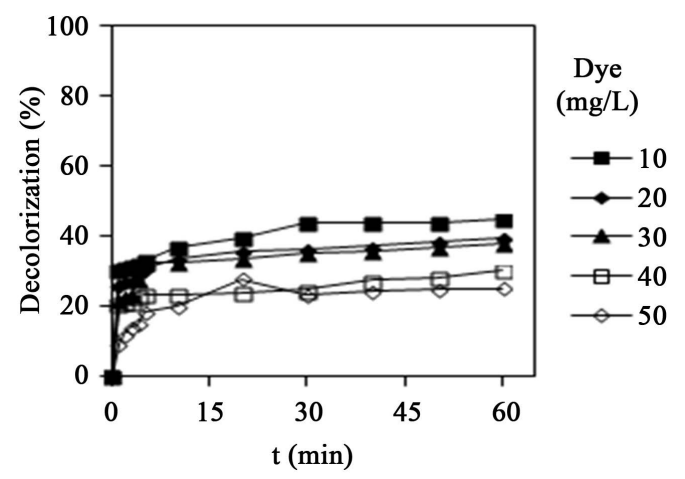

(g)

Figure 4. Effect of dye concentration on enzymatic decolorization of dyes from single and binary systems. ((a)-(c): single system; (e): DR60-DB56; (f) and (g): DR60-DY54). (a) DR60; (b) DY54; (c) DB56; (d) DR60 in binary system (DR60-DB56); (e) DB56 in binary system (DR60-DB56); (f) DR 60 in binary system (DR60-DY54); (g) DY 54 in binary system (DR60-DY54). 
Saturation curve for aimmobilized enzyme showing the relation between the concentration of substrate and rate of dye decolorization has been indicated in Figure 5. According to Figure 5, increasing dye concentration at lower concentration increases rate of dye decolorization linearly, but from given dye concentration, increasing dye concentration has not any specific effect on increasing dye decolorization rate (Maximum rate of dye decolorization) [16].

Hanes-Woolf plots were made from the initial rates obtained at varying dye concentrations while amount of enzyme was held constant (Figure 5 and Figure 6). According to the data of Table 1 , the lower $K_{m}$ value was estimated for oxidation of DB56 by immobilized laccase in single system, suggesting that this compound is well susceptible to immobilized laccase enzyme attack in compare with DR60and DY54 [16]. Furthermore, the lower $\mathrm{K}_{\mathrm{m}}$ value was estimated for oxidation of DB56and DY54by free laccase in DR60-DB56and DR60-DY54 systems, suggesting that DB56 and DY54 are well susceptible to immobilized laccase enzyme attackinDR60-DB56 and DR60-DY54 [16].

\section{Conclusions}

Immobilized Laccase enzyme has a significant effect on decolorizing of DR60, DB56 and DY54 from single and Binary systems. Furthermore, the optimized laccase enzyme concentration, reaction time and $\mathrm{pH}$ for decolorization of DR60,

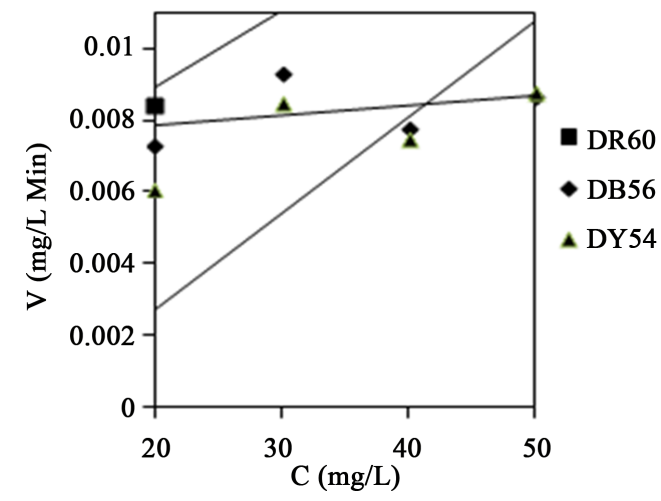

(a)

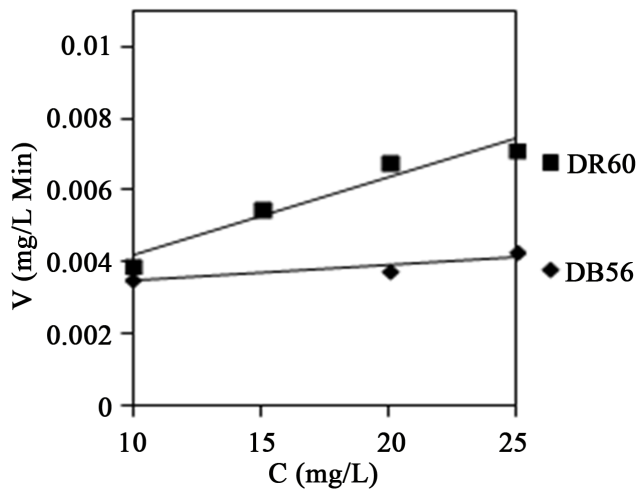

(b)

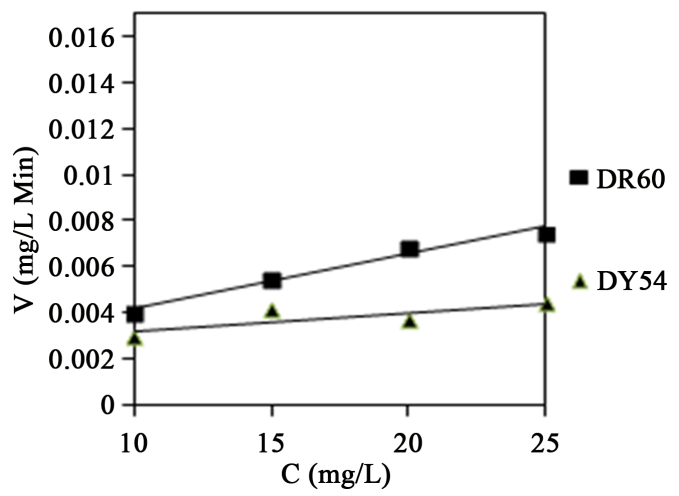

(c)

Figure 5. Saturation curve of enzyme during the enzymatic decolorization of dyes from single and binary systems. ((a) single system; (c): binary system). 


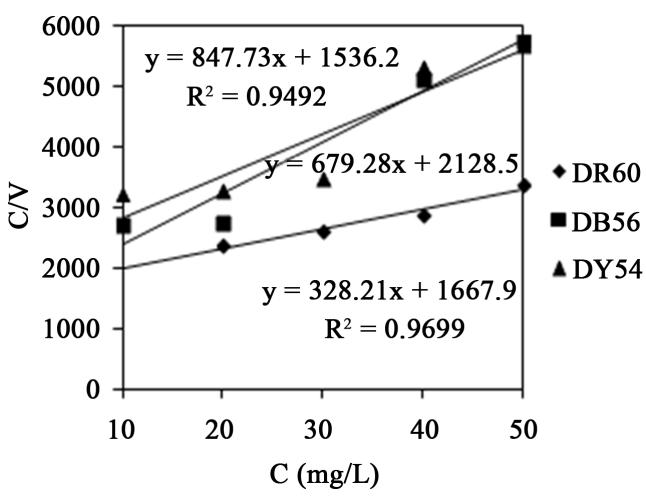

(a)

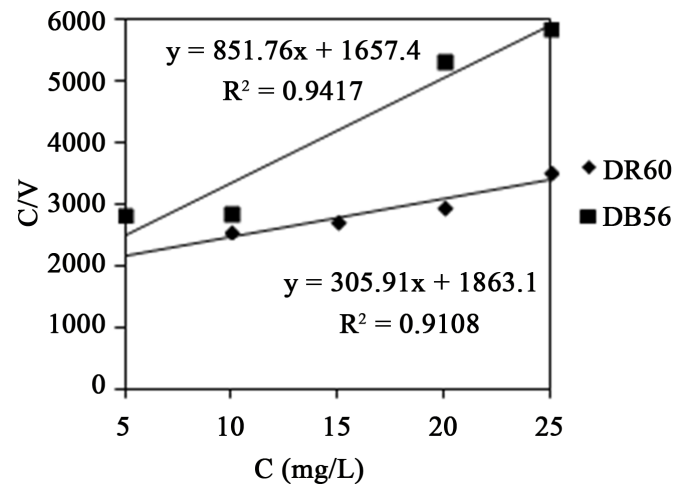

(b)

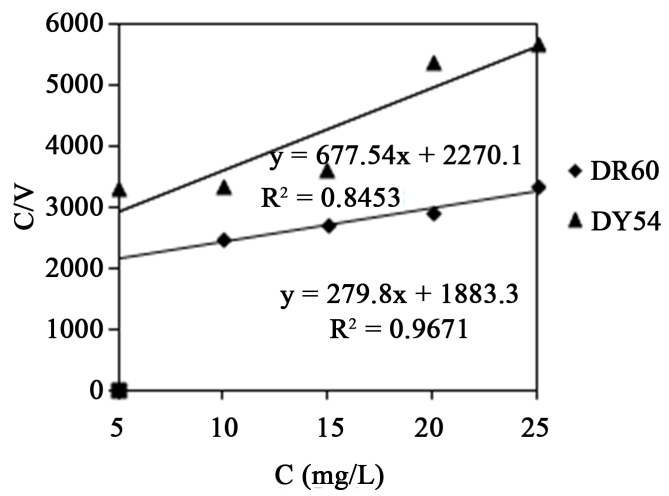

(c)

Figure 6. Linearization plots: A-Hanes-Woolf plot of enzymatic decolorization of dyes from single and binary systems. ((a) single system; (c) binary system).

DB56 and DY54 from single and binary systems were $500 \mathrm{mg} / \mathrm{L}$ (for DR60 and DY54) and $400 \mathrm{mg} / \mathrm{L}$ (for DB56), $20 \mathrm{~min}$ and 3, respectively.

Dye decolorization kinetics followed Michaelis-Menten Model. The results showed that enzymatic process using immobilized laccase was effective method to decolorize dyes from single and binary systems.

\section{Acknowledgements}

This work was done in the Farrokh Sepehr Kashan Company. Mr. Hossein Farrehi, Ali Farrahi and Mr. Ahmad Farrahi are grateful for the financial support.

\section{References}

[1] Mohajershojaei, K., Khosravi, A. and Mahmoodi, N.M. (2013) Decolorization of Dyes Using Laccase Enzyme from Single and Binary Systems. Desalination and Water Treatment, 52, 1895-1902.

[2] Shojaei, K.M., Khosravi, A. and Mahmoodi, N.M. (2014) Decolorization of Dyes Using Immobilized Laccase Enzyme on Zinc Ferrite Nanoparticle from Single and Binary Systems. Fibers and Polymers, 15, 2139-2145 https://doi.org/10.1007/s12221-014-2139-y

[3] Shojaei, K.M., Mahmoodi, N.M. and Khosravi, A. (2015) Decolorization of Dyes Using Immobilized Laccase Enzyme on to Titania Nanoparticle and Decolorization of Dyes from Single and Binary Systems. Biotechnology and Bioprocess Engineering, 
20, 109-116. https://doi.org/10.1007/s12257-014-0196-0

[4] Moorthi, P.S., Selvam, S.P., Kalaveni, A.S., Murugesan, K. and Kalaichelvan, B. (2007) Decolorization of Textile Dyes and Their Effluents Using White Rot Fungi, African Journal of Biotechnology, 6, 424-429.

[5] Pierce, J. (1994) Color in Textile Effluents-The Origins of the Problem. Coloration Technology, 110, 131-134. https://doi.org/10.1111/j.1478-4408.1994.tb01624.x

[6] Posczynski, A. and Crawford, R.L. (1995) Potential for Bioremediation of Xenobiotic Compounds by White Rot Fungus Phanerochaete chrysosporium. Biotechnology Progress, 11, 368-379. https://doi.org/10.1021/bp00034a002

[7] Couto, S.R. and Tocaherrera, J.L. (2006) Laccase in Textile Industry. Biotechnology and Molecular Biology Reviews, 1, 115-120.

[8] Davis, S. and Burns, R.G. (1992) Covalent Immobilization of Laccase on Activated Carbon for Phenolic Effluent Treatment. Applied Microbiology and Biotechnology, 37, 474-479. https://doi.org/10.1007/BF00180972

[9] Rogalski, J., Jozwik, E., Hatakka, A. and Leonowicz, A. (1995) Immoblization of Laccase from Phlebaradiata on Controlled Porosity Glass. Journal of Molecular Catalysis, 95, 99-108. https://doi.org/10.1016/1381-1169(94)00165-0

[10] Tischer, W. and Wedekind, F. (1999) Immobilized Enzyme: Methodsand Applications. Topics in Current Chemistry, 200, 96-100.

https://doi.org/10.1007/3-540-68116-7_4

[11] Fernandez, M., Sanroman, M.A. and Moldes, D. (2013) Recent Developments and Applications of Immobilized Laccase. Biotechnology Advances, 31, 1808-1825. https://doi.org/10.1016/j.biotechadv.2012.02.013

[12] Tehrani-Bagha, A.R., Shoushtari, A., Malek, R.M.A. and Abdous, M. (2004) Effect of Chemical Oxidation Treatment on Dyeability of Polypropylene. Dyes and Pigments, 63, 95-100. https://doi.org/10.1016/j.dyepig.2003.12.017

[13] Mahmoodi, N.M. (2013) Article title. Mater. Res. Bullet., 48, 4255. https://doi.org/10.1016/j.materresbull.2013.06.070

[14] Hai, F.I., Yamamoto, K. and Fukushi, K. (2007) Hybrid Treatment Systems for Dye Wastewater. Critical Reviews in Environmental Science and Technology, 37, 315377. https://doi.org/10.1080/10643380601174723

[15] Katuri, K.P., Mohen, S.V., Sridhar, S., Pati, B.R. and Sarma, P.N. (2009) LaccaseMembrane Reactors for Decolorization of an Acid Azodye in Aqueous Phase: Process Optimization. Water Research, 43, 3647-3658. https://doi.org/10.1016/j.watres.2009.05.028

[16] Michniewicz, A., Ledakowicz, S., Ullrich, R. and Hofrichter, M. (2008) Kinetics of the Enzymatic Decolorization of Textile Dyes by Laccase from Cerrena Unicolor, Dyes Pigments, 77, 295-302. https://doi.org/10.1016/j.dyepig.2007.05.015 
Submit or recommend next manuscript to SCIRP and we will provide best service for you:

Accepting pre-submission inquiries through Email, Facebook, LinkedIn, Twitter, etc. A wide selection of journals (inclusive of 9 subjects, more than 200 journals)

Providing 24-hour high-quality service

User-friendly online submission system

Fair and swift peer-review system

Efficient typesetting and proofreading procedure

Display of the result of downloads and visits, as well as the number of cited articles Maximum dissemination of your research work

Submit your manuscript at: http://papersubmission.scirp.org/

Or contact msa@scirp.org 